\title{
ANALISIS STRATEGI PEMASARAN UNTUK MENINGKATKAN PENJUALAN MOTOR MERK YAMAHA MIO M3 125 PADA PT . BAHANA PAGAR ALAM BANDAR LAMPUNG
}

\author{
Rinaldy Tri Saputra(1), Husna Purnama ${ }^{(2)}$, Novalia $^{(3)}$ \\ Fakultas Ekonomi Universitas Sang Bumi Ruwa Jurai \\ rinaldy.t_s@gmail.com, husna.purnama@fe.saburai.ac.id,novalia@fe.saburai.ac.id
}

\begin{abstract}
Abstrak. Objek penelitian ini adalah PT Bahana Cahaya Sejati cabang Lampung Jl. Z.A Pagar Alam No. 111 Rajabasa Kota Bandar Lampung. Penelitian ini dilakukan di lokasi lingkungan kantor PT Bahana Pagar Alam. Penelitian ini melibatkan kepala marketing dan seluruh karyawan PT Bahana Pagar Alam. Dipilihnya lokasi ini sebagai tempat penelitian karena terdapat suatu masalah penurunan penjualan pada produk PT. Bahana Pagar Alam. Pengumpulan data penelitian menggunakan teknik sampel dalam penelitian ini menggunakan teknik non probability purposive sampling. Non probability purposive sampling adalah teknik pengambilan sampel berdasarkan dengan suatu pertimbangan tertentu dengan cara menentukan terlebih dahulu kriteria responden. Sampel yang diambil dalam penelitian ini adalah 10 karyawan yang terdaftar di perusahaan tersebut dan 10 konsumen yang membeli kendaraan di perusahaan tersebut. Berdasarkan hasil perhitungan dalam Matrik IE (internal - eksternal), PT. Bahana Pagar Alam terletak pada sel 2, yaitu dengan memiliki faktor eksternal yang tinggi dan faktor internal yang sedang. Sedangkan berdasarkan hasil dari analisis SWOT strategi yang cocok untuk meningkatkan penjualan produk Yamaha "Mio M3 125" adalah strategi SO dan WO.
\end{abstract}

Kata kunci: Analisis SWOT, Eksternal, Internal, Pemasaran, Peningkatan.

\section{PENDAHULUAN}

\section{Transportasi}

atau

kendaraan merupakan salah satu kebutuhan sekunder manusia yang harus dipenuhi, disamping kebutuhan primer akan sandang, pangan dan papan. Kendaraan merupakan alat kegiatan transportasi manusia untuk melakukan interaksi dengan dunia luar untuk mencapai kesehjateraan. Dewasa ini, perusahaan kendaraan atau transportasi diperhadapkan pada kondisi persaingan yang semakin meningkat dalam keterbukaan bisnis.

Dengan keadaan seperti ini, tentu saja tidak menutup kemungkinan perusahaan transportasi tersebut akan bersaing ketat dengan perusahaan pesaing yang mengeluarkan produk sejenis.Perusahaan hendaknya menyadari bahwa dengan adanya persaingan tersebut sangat sulit bagi perusahaan untuk membangun reputasi perusahaan, demikian pula sebaliknya sangat mudah untuk kehilangan reputasi perusahaan tersebut (Supariyani, 2004).

Kondisi ini menuntut perusahaan harus lebih kreatif dan inovatif dengan menawarkan sesuatu yang bernilai lebih, dibanding yang dilakukan pesaing. Inilah yang dituntut oleh pasar yang menjadi fokus atau sasaran untuk bersaing. Pada umumnya perusahaan berupaya untuk memenuhi harapan konsumen, dengan membangun kepercayaan dalam suatu hubungan jangka panjang antara perusahaan dan pelanggannya. Hubungan ini harus dapat ditingkatkan dari waktu ke waktu misalnya pelayanannya, kualitas produknya, dan sebagainya(Supariyani, 2004).

Setiap perusahaan mempunyai tujuan untuk mencari keuntungan seoptimal mungkin. Untuk mencapai tujuan tersebut, setiap perusahaan mempunyai manajemen strategi pemasaran yang berbeda-beda. Perusahaan-perusahaan akan memilih 
strategi yang dirasa mampu mengembangkan perusahaanya masingmasing. Sebagaimana diketahui, bahwa dalam rangka pencapaian laba yang optimal, tentunya terlebih dahulu perusahaan harus mampu merebut pangsa pasar (market share) lebih besar dan ini hanya mungkin tercapai bila perusahaan cukup jeli melihat kebutuhan dan keinginan dari calon konsumen.

Setiap perusahaan mempunyai tujuan untuk mencari keuntungan seoptimal mungkin. Untuk mencapai tujuan tersebut, setiap perusahaan mempunyai manajemen strategi pemasaran yang berbeda-beda. Perusahaan-perusahaan akan memilih strategi yang dirasa mampu mengembangkan perusahaanya masingmasing. Sebagaimana diketahui, bahwa dalam rangka pencapaian laba yang optimal, tentunya terlebih dahulu perusahaan harus mampu merebut pangsa pasar (market share) lebih besar dan ini hanya mungkin tercapai bila perusahaan cukup jeli melihat kebutuhan dan keinginan dari calon konsumen.

Salah satu upaya yang dilakukan oleh perusahaan dalam melakukan peningkatan penjualan produk adalah dengan adanya strategi pemasaran. Dimana strategi pemasaran memiliki peran yang penting dalam meningkatkan penjualan untuk keberhasilan perusahaan. Oleh karena itulah strategi pemasaran harus dapat memberikan gambaran yang jelas dan teratur tentang apa yang dilakukan oleh perusahaan dan menggunakan setiap kesempatan atau peluang pada beberapa sasaran pasar(Supariyani, 2004).

PT. Bahana Pagar Alam yang beralamatkan di Jln. Pagar Alam No. 111 Bandar Lampung mengalami peningkatan penjualan produk kendaraan tiap bulannya, tetapi terdapat suatu masalah dengan terjadinya penurunan danketidakstabilan penjualan pada produk motor matic khususnya pada Yamaha M3 125 yang dijualnya pada tahun 2016. Hal ini bisa disebabkan karena parapesaing mengeluarkan produk sejenis (Sumber PT. Bahana Pagar Alam ).

Sebenarnya kesempatan untuk lebih meningkatkan penjualan masih sangat besar bagi PT. Bahana Pagar Alam, hal ini didukung dengan wilayah Kota Bandar Lampung sebagai pasar yang begitu luas dengan pertumbuhan penduduk yang tinggi berpengaruh besar terhadap kebutuhan sepeda motor yang terus meningkat setiap tahunnya. Dan merupakan tantangan tersendiri bagi dealer untuk bisa melakukan peningkatan penjualan sesuai dengan target yang direncanakan.

Supaya PT. Bahana Pagar Alam dapat lebihmeningkatkan penjualan produk motornya sehingga keuntungan yang dihasilkan lebih besar dan optimal, maka diperlukan analisis yang mendalam tentang kekuatan, kelemahan, peluang maupun ancaman yang dimiliki perusahaan. Analisis tersebut bertujuan untuk mengukur sejauh mana efektivitas dari perencanaan manajemen strategik dalam mengatasi dan mengantisipasi permasalahan-permasalahan yang akan muncul sewaktu-waktu.

Berdasarkan pertimbangan diatas, peneliti tertarik melakukan penelitian lebih lanjut mengenai penerapan strategi pemasaran yang dilakukan PT. Bahana Pagar Alam dalam meningkatkan penjualan Motor maticnya Khususnya Yamaha Mio M3 125 dengan judul: "Analisis Strategi Pemasaran untuk Meningkatkan Penjualan Motor Merk Yamaha Mio M3 125 pada PT. Bahana Pagar Alam"

\section{KAJIAN TEORI}

\section{Bauran Pemasaran}

Setelah menentukan pasar sasaran serta posisi pasar yang diinginkan, maka perlu didesain program agar produk tersebut dapat diterima pasar sasaran. Untuk itu 
diperlukan Bauran Pemasaran (Marketing Mix).

Philip Kotler dan Gary Armstrong dalam buku Principle of Marketing (2000) mengemukakan bahwa: "Bauran pemasaran adalah seperangkat alat pemasaran taktis dan terkontrol yang dipadukan oleh perusahaan untuk menghasilkan respon yang diinginkan pasar sasaran”.

"Bauran pemasaran adalah suatu istilah yang digunakan untuk menggambarkan kombinasi dari empat faktor yang merupakan inti dari suatu sistem perusahaan yaitu, produk, harga, promosi, dan distribusi" (Stanton, 1993)

Lamb, Hair, dan McDaniel (2001) mengemukakan bahwa "Bauran pemasaran adalah paduan strategi produk, distribusi, promosi, dan penentuan harga yang bersifat unik yang dirancang untuk menghasilkan pertukaran yang saling memuaskan dengan pasar yang dituju."

Dari definisi-definisi di atas maka dapat diambil kesimpulan bahwa marketing mix merupakan kombinasi dan empat variabel yang merupakan inti dari sistem pemasaran perusahaan dan dapat dikendalikan oleh perusahaan seefektif mungkin. Variabel-variabel tersebut dapat dikelompokkan menjadi empat kelompok utama yang dikenal dengan $4 \mathrm{P}$, yaitu:

1. Produk (Product), menurut Philip Kotler dan Gary Armstrong, Principle of Marketing (2001) "Produk adalah segala sesuatu yang dapat ditawarkan ke pasar untuk mendapatkan perhatian, dibeli, dipergunakan, atau dikonsumsi dan yang dapat memuaskan keinginan atau kebutuhan."

2. Harga (Price), menurut Philip Kotler dan Gary Armstrong, Principle of Marketing (2001) "Harga adalah jumlah uang yang dibebankan untuk suatu produk atau jasa. Lebih luas lagi, harga adalah jumlah dari seluruh nilai yang ditukar konsumen atas manfaat-manfaat memiliki atau mempergunakan produk atau jasa tersebut."

3. Promosi (Promotion), Philip Kotler dan Gary Armstrong dalam buku Principle of Marketing (2000) "Promosi adalah aktifitas memperkenalkan serta mengkomunikasikan keunggulan produk baru serta membujuk pelanggan sasaran untuk membelinya."

4. Tempat/Distribusi (Place), menurut Philip Kotler dan Gary Armstrong dalam buku Principle of Marketing (2000) "Distribusi adalah berbagai kegiatan yang dilakukan perusahaan untuk membuat produknya mudah diperoleh dan tersedia untuk konsumen sasarannya “.

\section{Macam-macam Strategi Pemasaran}

Berikut ini adalah macam-macam dari strategi pemasaran.

1. Pemimpin Pasar

Perusahaan ini diakui oleh industri yang bersangkutan sebagai pemimpin pasar dan perusahaan tersebut memiliki pangsa pasar terbesar pada pasar yang sama. Strategi-strategi yang diterapkan pemimpin pasar adalah :

- Perluasan pasar total, yaitu dengan cara mengembangkan kegunaan produksi yang baru, pemakai baru atau penggunaan yang lebih banyak oleh para pembeli.

- Perluasan pangsa pasar, yaitu dengan cara memperluas segmentasi pasar atau memasuki pasar-pasar baru.

- Melindungi pangsa pasar, yaitu menggunakan taktik pemasaran inovatif atau melakukan tindakan pembelaan terhadap pihak pesaing.

2. Penantang Pasar

Perusahaan ini memiliki pangsa pasar yang lebih kecil dari pihak pemimpin pasar pada sebuah pasar yang sama. 
- Strategi penyerangan pemimpin pasar dengan langkah promosi atau penentuan harga secara agresif.

- Strategi pintu belakang, yaitu menghadapi pemimpin pasar dari belakang melalui tindakan strategi inovatif.

- Strategi guppy, yaitu memperbesar pangsa pasar dengan jalan menghabisi perusahaan-perusahaan yang lebih kecil.

\section{Pengikut Pasar}

Kelompok ini terdiri dari perusahaan yang mengambil sikap tidak menantang pemimpin pasar tetapi mereka puas dengan cara menyesuaikan diri terhadap kondisi pasar yang ada. Strategi-strategi yang digunakan adalah :

o Strategi meniru pemimpin pasar, yaitu usaha untuk meniru pemimpin pasar sejauh mungkin tanpa mengambil sikap menantang.

- Strategi penyesuaian, yaitu dengan cara mengikuti strategi-strategi pemimpin pasar dan pihak pesaing tanpa terlihat dalam kegiatan konfrontasi langsung.

\section{Perelung Pasar}

Kelompok ini adalah perusahaanperusahaan yang beroperasi di sebuah wilayah geografi atau wilayah pembeli tanpa pesaing. Strategi-strategi yang dapat diterapkan oleh perusahaan :

- Strategi relung pasar, yaitu dengan cara melakukan spesialisasi menurut wilayah geografis dan beraksi cepat terhadap pembeli.

- Strategi relung produksi, yaitu perusahaan produksi-produksi dan jasa-jasa yang bersifat unik bagi pembeli yang dilayani.

\section{METODE PENELITIAN}

\section{Objek Penelitian}

Adapun objek penelitian ini adalah PT Bahana Cahaya Sejati cabang Lampung Jl. Z.A Pagar Alam No. 111 Rajabasa Kota Bandar Lampung. Penelitian ini dilakukan di lokasi lingkungan kantor PT Bahana Pagar Alam. Penelitian ini melibatkan kepala marketing dan seluruh karyawan PT Bahana Pagar Alam. Dipilihnya lokasi ini sebagai tempat penelitian karena terdapat suatu masalah penurunan penjualan pada produk PT. Bahana Pagar Alam.

\section{Teknik Pengumpulan Data}

1. Interview / Wawancara adalah teknik pengumpulan data dengan jalan mengadakan komunikasi langsung dengan pihak-pihak yang mengetahui langsung dengan masalah yang diteliti. Adapun pihak-pihak yang dimintai keterangannya dalam penelitian adalah Kepala Marketing PT. Bahana Pagar Alam di Bandar Lampung. Interview dilakukan oleh peneliti untuk mendapatkan data tentang Visi perusahaan, Misi perusahaan dan sejarah singkat perusahaan.

\section{Observasi}

yaitu pengumpulan data dengan jalan pengamatan langsung pada objek penelitian. Obesrvasi dilakukan oleh peneliti untuk mengamati kegiatan perusahaan PT. Bahana Cahaya Sejati.

\section{Dokumentasi}

yaitu merupakan sumber informasi berupa bahan-bahan tertulis atau datadata yang tercatat pada PT. Bahana Pagar Alam di Bandar Lampung. Dokumentasi dilakukan peneliti untuk memperoleh data struktur organisasi perusahaan serta mendapatkan data laporan penjualan PT. Bahana Pagar Alam. 


\section{Teknik Sampel}

Teknik sampel dalam penelitian ini menggunakan teknik non probability purposive sampling. Non probability purposive sampling adalah teknik pengambilan sampel berdasarkan dengan suatu pertimbangan tertentu dengan cara menentukan terlebih dahulu kriteria responden. Kriteria konsumen yang dijadikan sampel adalah pelanggan yang membeli minimal dalam jangka waktu satu bulan terakhir. Selanjutnya menentukan besaran sampel. Besaran sampel merupakan banyaknya individu, subjek atau elemen dari populasinya yang diambil sebagai sampel. Menurut Fraenkel dan Wallen yang dikutip oleh Soehardi Sigit (1999) besarnya sampel minimum untuk penelitian ini adalah sebanyak 100 responden. Atas dasar pertimbangan diatas, maka sampel yang diambil dalam penelitian ini adalah 10 karyawan yang terdaftar di perusahaan tersebut dan 10 konsumen yang membeli kendaraan di perusahaan tersebut.

\section{Metode Analisis}

\section{Matrick BCG (Boston Consultative Group)}

Matricks BCG digunakan untuk mengetahui posisi PT. Bahana Pagar Alam dari pertumbuhan pangsa pasar. Jika sudah diketahui posisinya, maka akan ditentukan Strategi pemasaran apa yang dapat dilakukan oleh perusahaan.

Tahap analisis dilakukan dengan mengumpulkan data, yaitu data penjualan tahunan produk dan data penjualan produk pesaing yang digunakan untuk mengukur dan mengetahui tingkat pertubuhan pasar dan tingkat pasar relatif. Secara sederhana, tingkat pertumbuhan pasar market growth rate bisa dihitung dengan formula sebagai berikut :

$$
X_{N}=\frac{A_{N}-A_{N-1}}{B} \times 100 \%
$$

$$
\begin{array}{cl}
\underset{\text { Keterangan : }}{\mathrm{X}_{\mathrm{N}}} & =\underset{\text { Tingkat Pertumbuhan }}{ } \\
& \text { Pasar Tahun }(\mathrm{N}) \\
\mathrm{A}_{\mathrm{N}} & =\text { Volume Penjualan Industri } \\
& \text { Tahun }(\mathrm{N}) \\
\mathrm{A}_{\mathrm{N}-1}= & \text { Volume Penjualan Industri } \\
& \text { Tahun }(\mathrm{N}-1) \\
\mathrm{B} & =\text { Volume Penjualan }
\end{array}
$$

(Purwanto, (2008).

Sedangkan pangsa pasar relatif (relative market share) secara sederhana dapat dihitung dengan rumus (Rangkuti : 2006) :

$$
P_{p r}=\frac{A_{N}}{Y_{N}}
$$

Keterangan :

$$
\begin{aligned}
\mathrm{P}_{\mathrm{pr}} \quad= & \text { Pangsa Pasar Relatif } \\
\mathrm{A}_{\mathrm{N}}= & \text { Volume Penjualan } \\
& \text { Perusahaan Tahun }(\mathrm{N}) \\
\mathrm{Y}_{\mathrm{N}} \quad= & \text { Volume Penjualan } \\
& \text { Perusahaan Pesaing Tahun } \\
& (\mathrm{N}) .
\end{aligned}
$$

\section{Analisis SWOT}

Analisis SWOT digunakan untuk merumuskan strategi pemasaran berdasarkan kekuatan, kelemahan, peluang dan ancaman PT. Bahana Pagar Alam. Tahap analisis dilakukan dengan membuat matrik IFAS (Internal Strategy Factors Analyis Summary) dan matrik EFAS (Eksternal Strategy Factors Analyis Summary). 


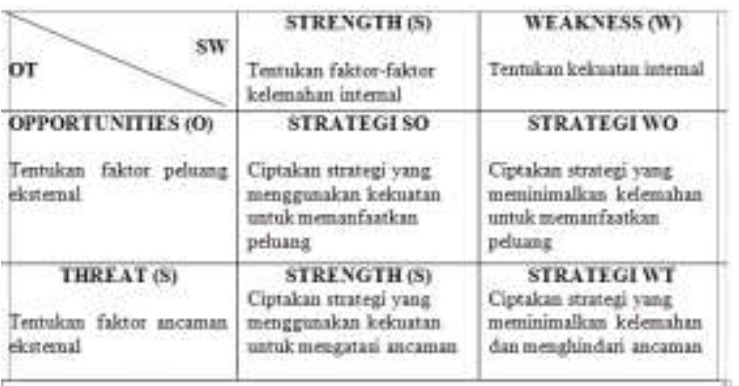

Gambar 1. Matriks SWOT

HASIL DAN PEMBAHASAN

\section{Analisis Internal (Internal Factors analysis Summary)}

Pada analisis lingkungan Internal ini, yang dikaji adalah faktor-faktor yang berada didalam perusahaan yaitu berupa kekuatan dan kelemahan yang dimiliki perusahaan. Adapun sebelum pembuatan Tabel Ringkasan Analisis Faktor-faktor Strategi Internal perlu diketahui terlebih dahulu faktor-faktor internal perusahaan. Dari hasil kuesioner yang telah diberikan kepada karyawan PT. Bahana Pagar Alam maka dapat diketahui yang menjadi faktorfaktor strategi Internal pada dealer tersebut adalah sebagai berikut :

- Faktor-faktor yang menjadi kekuatan :

1. Potongan Penjualan

2. Pelayanan yang ramah

3. Harga lebih murah dari pesaing

4. Reward kepada konsumen

- Faktor-faktor yang menjadi kelemahan :

1. Kurangnya promosi

2. Kurangnya tenaga pemasaran

3. kurangnya karyawan

4. Tidak ada bonus terhadap karyawan

Total skor analisis faktor-faktor internal dapat dilihat pada Tabel 1.

Tabel 1. Ringkasan Faktor IFAS PT. Bahana Pagar Alam.

\begin{tabular}{|c|c|c|c|}
\hline (1) & (2) & (3) & (4) \\
\hline Faktor-faktor Strategis internal & Bobot & Rating & Skor \\
\hline Kekeatan & & & \\
\hline 1) Potongan Penjualan & 0.20 & 3 & 0.60 \\
\hline 2) Pelayanan yang ramah dan cepat & 0.20 & 2 & 0.40 \\
\hline 3) Harga lebih murah dari pesaing & 0.20 & 3 & 0.60 \\
\hline 4) Reward kepada konsumen & 0.10 & 3 & 0.30 \\
\hline Jumiah Kekuatan & 0.70 & & 1.90 \\
\hline Kelemuahan & & & \\
\hline 1) Kurangnya promosi & 0,10 & 3 & 0.30 \\
\hline 2) Kurangnya tenaga pemasaran & 0.05 & 1 & 0.05 \\
\hline 3) Kurangnya karyawan & 0.10 & 2 & 0.20 \\
\hline 4) tidnk ada bosus untuk karyawan & 0.05 & 1 & 0,05 \\
\hline Jumlah Kelemahan & 0.30 & & 0.60 \\
\hline Total $3 \mathrm{kor}$ & 1.00 & & 2.50 \\
\hline
\end{tabular}

Dari hasil analisis Tabel 1. faktorfaktor internal tersebut dapat diketahui bahwa nilai skor faktor strategi internal adalah 2,50. Dalam matrik Internaleksternal (IE) nilai 2,50 masuk dalam kategori rata-rata (sedang).

Sedangkan faktor kekuatan terbesar PT. Bahana pagar Alam terdapat pada potongan penjualan dari hasil quistioner dengan nilai 0,60. Menurut Henry Simamora (2000) mengemukakan bahwa "Potongan penjualan adalah potongan tunai (cashdiscount) yang ditawarkan kepada para pelanggan yang membeli barangbarang dagangan secara kredit.

Faktor kelemahan terbesar yang dimiliki oleh PT. Bahana Pagar Alam adalah kurangnya tenaga pemasaran dari hasil tabulasi quisioner dengan nilai 0,05. Menurut Hasibuan (2007) Sales atau tenaga pemasaran adalah setiap orang yang bekerja dengan perusahaan yang menjual produk yang dihasilkan perusahaan kepada suatu konsumen.

\section{Analisis eksternal (eksternal Factors analysis Summary)}

Pada analisis lingkungan eksternal, perusahaan mengkaji faktor-faktoryang berada diluar perusahaan yaitu berupa peluang dan ancaman yangdihadapi. Adapun sebelum pembuatan Tabel Ringkasan Analisis Faktor-faktorStrategi Eksternal perlu diketahui terlebih dahulu faktor-faktor eksternal perusahaan. Dari daftar pertanyaan yang telah diberikan 
kepada manajemen dan karyawan Dealer Bahana Pagar Alam maka dapat diketahui yang menjadi faktor-faktor strategi eksternal pada dealer tersebut adalah sebagai berikut :

1. Faktor-faktor yang menjadi peluang :

-Wilayah Bandar Lampung potensial untuk pasar

- Kebutuhan sepeda motor selalu meningkat setiap tahun Hubungan yang baik dengan pembeli

- Kemudahan pembelian mempengaruhi minat beli sepeda motor

2. Faktor-faktor yang menjadi ancaman :

- Krisis global

- Pesaing yang kuat

- Lokasi pesaing yang strategis

- Pesaing banyak melakukan promosi

- pemberitahuan yang negatif (boros BBM) terhadap produk Yamaha Mio

Total skor analisis faktor-faktor dapat dilihat pada Tabel 2 .

Tabel 2. Ringkasan EFAS PT. Bahana Pagar Alam

\begin{tabular}{|c|c|c|c|}
\hline (1) & (2) & (3) & (4) \\
\hline Faktor-falktor Strategis internal & Bobot & Rating & Sksor \\
\hline \multicolumn{3}{|l|}{ Peluang } & \\
\hline $\begin{array}{l}\text { 1) Wilayah Bandar lampuing } \\
\text { potensial untukpasar }\end{array}$ & 0.10 & 4 & 0.40 \\
\hline $\begin{array}{l}\text { 2) Kebutuhan scpeds motor selelu } \\
\text { meningkat setiag tahun }\end{array}$ & 0.15 & 3 & 0.45 \\
\hline 3) Hubungan yang baik dengan & 0.20 & 4 & 0.80 \\
\hline penbeli & 0.15 & 4 & 0.60 \\
\hline $\begin{array}{l}\text { 4) Kemidahun pembelian } \\
\text { mempenganuhi mimat beti sepeda } \\
\text { motor }\end{array}$ & & & \\
\hline Jumlah Peluang & 0.60 & & 2.25 \\
\hline \multicolumn{4}{|l|}{ Ancaman } \\
\hline 1) Krisis global & 0.10 & 2 & 0.20 \\
\hline 2) Pesaing yang kuat & 0.10 & 2 & 0.20 \\
\hline 3) Lokasi pesaing yans strategis & 0,10 & 2 & 0.20 \\
\hline 4). Pesaing banyak melakukan & 0.05 & 2 & 0.10 \\
\hline promosi & 0.05 & 1 & 0.05 \\
\hline $\begin{array}{l}\text { 5) Pemberitaan yang negatif (boros } \\
\text { BBM) terhadapproduk Yamaha } \\
\text { Mro MB } 125\end{array}$ & & & \\
\hline Jumlah Ancaman & 0.40 & & 0.75 \\
\hline Total skor & 1.00 & & 3.00 \\
\hline
\end{tabular}

Dari hasil analisis Tabel 2. faktorfaktor eksternal tersebut dapat diketahui bahwa nilai skor faktor strategi eksternal adalah 3,00. Dalam matrik Internaleksternal (IE) nilai 3,00 masuk dalam kategori tinggi. Sedangkan untuk faktor terbesar peluang yang dimiliki oleh PT.
Bahana Pagar Alam adalah hubungan yang baik dengan pembeli dengan nilai 0,80 .

PT. Bahana Pagar Alam telah memiliki hubungan yang baik dengan para pembeli hal ini dibuktikan dengan membentuk organisasi Humas (hubungan Masyarakat) dengan tujuan lebih mendekatkan perusahaan kepada masyarakat supaya masyarakat dapat mengenal PT. Bahana Pagar Alam. Sehingga faktor ini menjadikan Faktor terbesar peluang PT. Bahana Pagar Alam untuk menarik Konsumen dan membangun citra image perusahaan.

Hubungan atau Relationship adalah upaya mengenal konsumen lebih baik, sehingga perusahaan dapat memenuhi needs and wants mereka dalam jangka panjang. Definisi ini di dukung juga oleh pendapat Berry dalam Hennig-Thurau dan Hansen (2000) mendefinisikan istilah relationship ini sebagai upaya menarik, mengelola, dan memberikan berbagai jasa perusahaan dengan memanfaatkan hubungan baik dengan pelanggan.

\section{Analisis SWOT (Strength, Weakness, Opportunity, Threat)}

Analisis ini bertujuan untuk mencocokkan peluang-peluang dan ancaman-ancaman eksternal yang dihadapi perusahaan dengan kekuatan dan kelemahan internalnya untuk menghasilkan alternatif strategi. Analisis inimenggunakan suatu matriks yang terdiri dari 9 sel yang berisikan 4 sel alternatif strategi yang disebut dengan Matrik SWOT.

Berikut ini merupakan alternatif strategi yang bisa dilakukan oleh dealer PT. Bahana Pagar Alam yang sudah di jelaskan dalam faktor eksternal dan faktor inernal, kemudian terangkum dalam Gambar 2. 


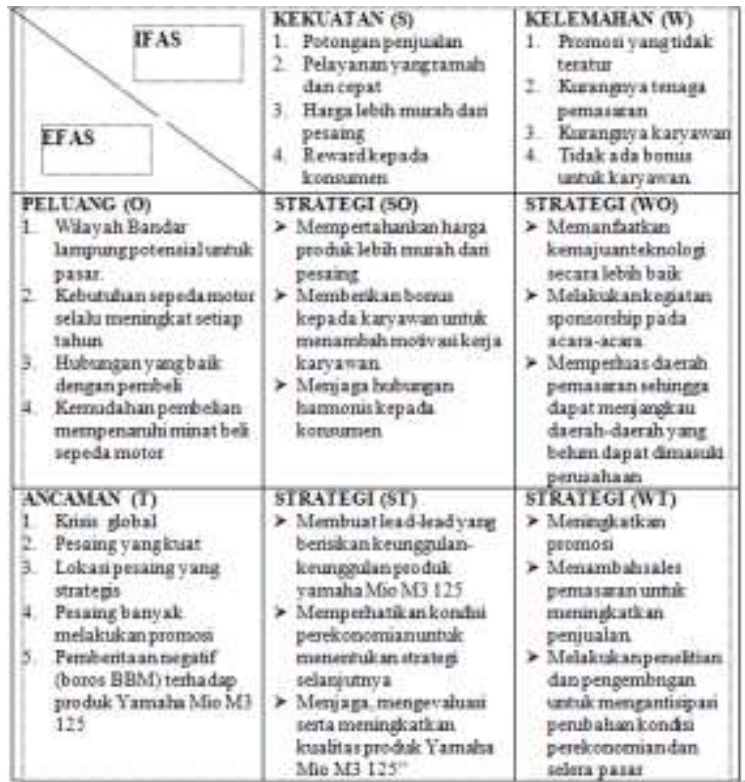

Gambar 2. Matriks SWOT

Penjelasan dari alternatif strategi yang dihasilkan pada Matriks SWOT tersebut adalah :

1. Mempertahankan produk lebih murah terhadap produk pesaing. Dengan harga yang lebih rendah dan kualitas yang lebih bagus dan bersaing, hal ini akan menciptakan peluang yang sangat besar bagi perusahan untuk mendapatkan laba yang lebih besar dan memperluas pasar yang akan dimasuki.

2. Memberikan bonus kepada karyawan. Bonus merupakan pemberian penghasilan tambahan dari perusahaan selain dari penghasilan intensif, dengan memberikan bonus terhadap semua karyawan,

3. Memanfaatkan teknologi secara lebih baik. Kemajuan teknologi memungkinkan perusahaan untuk berinovasi dan berkreatifitas guna menghasilkan kualitas produk yang lebih baik.

4. Melakukan kegiatan sponsorship pada acara-acara. Sponsorship penting untuk melihat kredibilitas perusahaan dalambersosial kemasyarakatan. Sponsorship dapat dilakukan pada saat ada event organizer melakukan kegiatan yang mengundang massa, seperti pada saat : perayaan HUT Lampung, HUT Universitas, konaer musik dan lain-lain.

5. Memperluas daerah pemasaran, dengan memperluas daerah pemasaran perusahaan, sehingga perusahaan dapat lebih banyak menjual produknya seperti membuka cabang di kabupatenkabupaten yang ada di di Provinsi Lampung.

6. Membuat Lead-Lead yang berisi tentang keunggulan produk Yamaha Mio M3 125. Lead-Lead Katalog dibuat selengkap dan semenarik mungkin yang mengupastentang keunggulankeunggulan produk Yamaha disertai daftar harga seperti dalam brosur. ini Lead-Lead dapat membantu pencitraan yang baik terhadap produk Yamaha Mio M3 125

7. Meningkatkan promosi, membuat spanduk atau baliho yang dipasangpada keramaian.

8. Menambah karyawan di bidang pemasaran. Sama seperti Dengan memperluas daerah pemasaran perusahaan, dengan menambah karyawan bidang pemasaran akan menambah daya jelajah perusahaan, sehingga perusahaan dapat lebih banyak menjual produknya seperti membuka cabang di kabupaten-kabupaten yang ada di di Provinsi Lampung .

\section{Rumusan Kombinasi Strategi Matrik SWOT}

Berdasarkan Hasil Analisis pada matrik IFAS dan EFAS maka dapat disimpulkan pada Tabel 3 .

Tabel 3. Rumusan Kombinasi Matriks SWOT

\begin{tabular}{|c|c|c|}
\hline IFA & Strength (S) & Weatuess (W) \\
\hline Opportunity $(0)$ & $\begin{array}{l}\text { Strutegl (SO) } 1.90+ \\
2.25=-1.15\end{array}$ & $\begin{array}{l}\text { Strategi (WO) } 0.60 \\
-2.25=2.84\end{array}$ \\
\hline Threat (S) & $\begin{array}{l}\text { Stroteg (ST) } 1.90+ \\
0.75=2.65\end{array}$ & $\begin{array}{l}\text { Strntegi (WT) } 2.60+ \\
0.75+135\end{array}$ \\
\hline
\end{tabular}


Berdasarkan hasil perhitungan kombinasi matrik SWOT maka strategi yang paling dominan di gunakan untuk meningkatkan penjualan motor MIO M3 125 pada PT. Bahana Pagar Alam, maka dapat disimpulkan yaitu Strategi SO dengan nilai 4,15 dan strategi $\mathrm{WO}$ dengan nilai 2,84 .

Berdasarakan hasil dari matrik BCG, Matrik Eksternal-internal dan analisis SWOT PT. Bahana Pagar Alam, dan untuk menjawab pemasalahan pada PT. Bahana pagar Alam maka strategi yang dapat dipakai dalam meningkatkan penjualan produk khususnya Yamaha "Mio M3 125" adalah Dari analisis matrik BCG, PT. Bahana Pagar Alam berada dalam kuadran stars, strategi pemasaran yang dapat digunakan adalah integrasi ke depan, dengan menambah beberapa sales pemasaran untuk meningkatkan penjualan produk.

Dari hasil analisis faktor eksternal dan internal kemudian dituangkan dalam matrik eksternal-internal posisi PT. Bahana Pagar Alam berada di kolom Sel 2 pada strategi Integrasi Horizontal. Maka strategi yang harus dilakukan oleh PT. Bahana Pagar Alam untuk meningkatkan penjualan adalah denganmelakukan pembelian salah satu dari para pesaing PT. Bahana Pagar alam.

Dari hasil analisis SWOT pada Gambar 2. maka strategi yang paling dominan untuk meningkatkan penjualan Yamaha "Mio M3 125" pada PT. Bahana Pagar alam adalah Strategi SO dan WT.

Strategi SO adalah strategi yang dilakukan dengan mengkombinasikan antara kekuatan (S) dan peluang (O). Strategi ini dibuat berdasarkan jalan pikiran perusahaan, yaitu dengan memanfaatkan seluruh kekuatan untuk merebut dan memanfaatkan peluang sebesar-besarnya. Dalam strategi ini yang dapat dilakukan adalah : a) Mempertahankan harga produk lebih murah dari pesaing

b) Memberikan bonus kepada karyawan untuk menambah motivasi kerja karyawan.

Starategi WO adalah strategi yang dilakukan dengan mengkombinasikan antara kelemahan (W) dan peluang (O). Strategi WO merupakan strategi dengan meminimalisasi kelemahan dan memaksimalkan peluang. Dalam hal ini strategi yang dilakukan adalah :

1. Memanfaatkan kemajuan teknologi secara lebih baik

2. Melakukan kegiatan sponsorship pada acara-acara. Memperluas daerah pemasaran sehingga dapat menjangkau daerah-daerah yang belum dapat dimasuki perusahaan.

\section{KESIMPULAN}

\section{Kesimpulan}

Berdasarkan penelitian yang telah dilakukan dapat disimpulkan bahwa dari analisis faktor strategi eksternal menunjukkan bahwa nilai skor tertimbang adalah 3,00, ini berarti respon manajemen perusahaan terhadap lingkungan eksternal adalah tinggi pada skala pengukuran matrik IE (internal - eksternal). Sedangkan Analisis faktor strategi internal menunjukkan bahwa nilai skor tertimbang adalah 2,50, ini berarti respon manajemen perusahaan terhadap lingkungan internal adalah sedang pada skala pengukuran Matrik IE (internal - eksternal). Berdasarkan hasil perhitungan dalam Matrik IE (internal - eksternal), PT. Bahana Pagar Alam terletak pada sel 2, yaitu dengan memiliki faktor eksternal yang tinggi dan faktor internal yang sedang. Sedangkan berdasarkan hasil dari analisis SWOT strategi yang cocok untuk meningkatkan penjualan produk Yamaha "Mio M3 125" adalah strategi SO dan WO. 


\section{Saran}

Dalam melakukan pemasaran perusahaan perlu membuat strategi pemasaran yang lebih baik dengan memperhatikan strategi sebelumnya. Tetapi yang perlu dipertahankan adalah strategi harga dan potongan penjualan itu sendiri, dari segi pandang inilah perusahaan dapat menaikkan harga dengan catatan tetap dibawah harga pesaing.

\section{DAFTAR PUSTAKA}

Alma, Buchari. 2006. Manajemen dan Pemasaran Jasa (Edisi Revisi). Cetakan Ketujuh. Bandung: CV.Alfabeta.

Arifin. 2011. Analisis Strategi Pemasaran Bisnis Distro (Distribution Store) di Kawasan Jalan Mataram, Yogyakarta. Skripsi. Yogyakarta: FE UNY.

Charles, W Lamb, Joseph S Hair dan Carl Mc daniel. 2001. Pemasaran 1, edisi lima. Jakarta : PT. Salemba Empat.

David, Fred.R. 2006. Manajemen Strategis Konsep. Jakarta: PT. Salemba Empat.

Hari, Wibowo. 2010. Analisis Strategi Pemasaran Wisata pada Dinas Kebudayaan dan Pariwisata Kabupaten Gunung Kidul. Skripsi. Yogyakarta: FE UNY

Kotler, Philip. 1991. Manajemen Pemasaran, Analisis, Perencanaan dan Pengendalian. Jilid I dan jilid 6. Diterjemahkan oleh Jaka Wasana. Jakarta: PT. Prenhalindo, Jakarta.
Kotler, Philip dan Armstrong, Gary. 2008. Prinsip - Prinsip Pemasaran. diterjemahkan oleh Bob Sabran. Jilid 1. Edisi keduabelas. Jakarta: Erlangga.

Munadi, Fandi. 2010. Analisis Strategi Pemasaran untuk Meningkatkan Penjualan Kendaraan Motor pada CV Turangga Mas Motor. Jakarta: Skripsi. Fakultas Ekonomi Universitas Gunadarma.

Rangkuti, Freddy. 2006. Analisis Swot Teknik Membedah Kasus Bisnis. Jakarta: PT. Gramedia Pustaka Utama.

Santon, William J. 1993. Prinsip Pemasaran. Jakarta: Erlangga.

Siagian, P Sondang. 1999. Manajemen Stratejik, Bandung: PT Bumi Aksara.

Sugiyono. 2008. Metode Penelitian Bisnis Pendekatan Kuantitatif, Kualitatif, dan R\&D. Bandung: Penerbit Alfabeta.

Supariyani, Emmy. 2004. Pengaruh Biaya Pelaksanaan Promosi Melalui Pameran terhadap Tingkat Volume Penjualan pada PT Astra Internasional Tbk Isuzu Cabang Bogor. Jurnal Ilmiah Ranggagading Vol. 4, No. 1, April 2004. Pp. 69-74.

Zeithaml, Valarie Bitner. (2000). Service Marketing 2nd edition. Jakarta: PT Gramedia Pustaka Utama. 